\title{
PENERAPAN MODEL PEMBELAJARAN KOOPERATIF TIPE NUMBERED HEADS TOGETHER UNTUK MENINGKATKAN MINAT DAN HASIL BELAJAR IPS SEJARAH PADA SISWA KELAS VII.3 SMPN 7 DENPASAR
}

\author{
Filfiana Filda, Rulianto \\ Program Studi Pendidikan Sejarah, FKIP Universitas Mahasaraswati Denpasar \\ Email:viviana86282@gmail.com
}

\begin{abstract}
ABSTRAK
Tujuan penelitian ini adalah (1) untuk mengetahui apakah dengan menerapkan model pembelajaran kooperatif tipe Numbered Heads Together (NHT) dapat meningkatkan minat belajar IPS Sejarah pada siswa kelas VII.3 SMPN 7 Denpasar dan (2) untuk mengetahui apakah penerapan model pembelajaran kooperatif tipe Numbered Heads Together (NHT) dapat meningkatkan hasil belajar IPS Sejarah pada siswa kelas VII.3 SMPN 7 Denpasar. Metode yang di gunakan dalam penelitian ini adalah metode pembelajaran kooperatif tipe Numbered Heads Together (NHT) dengan pengumpulan data observasi, wawancara, dokumentasi, dan kuisioner. Penelitian menunjukan bahwa hasil belajar siswa dapat dilihat pada Siklus I bahwa nilai ranah kognitif siswa adalah rata-rata 6,75 dan ketuntasannya $52,7 \%$, dari ranah afektif nilai yang diperoleh siswa adalah amat baik $27,7 \%$, baik $58,3 \%$ dan cukup $13,3 \%$. Sedangkan dari ranah psikomotor nilai yang diperoleh siswa adalah amat baik $63,8 \%$, baik $27,7 \%$ dan cukup $8,3 \%$. Pada Siklus II nilai ranah kognitif siswa adalah rata-rata 80 dan ketuntasannya $100 \%$, dari ranah afektif nilai yang diperoleh siswa adalah amat baik $8,3 \%$, baik $8,3 \%$, sedangkan dari ranah psikomotor nilai yang diperoleh siswa adalah amat baik $94,4 \%$ dan baik $5,5 \%$.
\end{abstract}

Kata Kunci : model numbered heads together (NHT), minat belajar dan hasil belajar

\section{ABSTRACT}

The purpose of this study was (1) to find out whether applying the Numbered Heads Together (NHT) type of cooperative learning model could increase the interest in studying Social History History in Grade VII.3 students of SMPN 7 Denpasar and (2) to find out whether the application of the Numbered type cooperative learning model Heads Together (NHT) can improve social studies history learning outcomes for Grade VII.3 students of SMPN 7 Denpasar. The method used in this research is the Numbered Heads Together (NHT) type of cooperative learning method with observation, interview, documentation, and questionnaire data collection. Research shows that student learning outcomes can be seen in Cycle I that the cognitive domain value of students is an average of 6.75 and $52.7 \%$ completeness, from the affective domain the value obtained by students is very good $27.7 \%$, good $58.3 \%$ and enough $13.3 \%$. While from the psychomotor domain, the scores obtained by students were very good $63.8 \%$, good $27.7 \%$ and $8.3 \%$ sufficient. In Cycle II the value of the cognitive domain of students is an average of 80 and 100\% completeness, from the affective domain the value obtained by students is very good $8.3 \%, 8.3 \%$ good, while from the psychomotor domain the value obtained by students is very good $94,4 \%$ and good $5.5 \%$.

Keyword : model numbered heads together (NHT), learning interests and learning outcomes 


\section{PENDAHULUAN}

Pendidikan adalah upaya sadar dan terencana untuk mewujudkan suasana belajar dan proses pembelajaran agar peserta didik secara aktif mengembangkan potensi dirinya. Untuk mencaspainya maka diperlukan suatu proses pembelajaran yang dapat dilakukan di sekolah. Kegiatan pembelajaran di sekolah merupakan kegiataan utama dalam proses pendidikan pada umumnya yang bertujuan membawa anak didik atau siswa menuju pada keadaan yang lebih baik.

Keberhasilan suatu proses pembelajaran adalah dari ketercapaian siswa dalam mengikuti kegiatan pembelajaran, dalam hal ini perlu adanya upaya guru untuk meningkatkan hasil belajar siswa, meningkatkan partisipasi siswa dalam proses pembelajaran serta meningkatkan aktivitas belajar siswa sehingga proses pembelajaran dapat berlangsung dengan baik dan pencapaian tujuan pembelajaran yang dapat meningkatkan minat dan hasil belajar siswa. Namun pada kenyataannya minat dan hasil belajar IPS Sejarah pada siswa masih rendah.

Hal ini disebabkan karena kurangnya metode yang digunakan dalam proses pembelajaran. Guru masih bersifat informatif artinya guru yang aktif dalam proses pembelajaran sementara siswa hanya mendengarkan, sehingga mata pelajaran IPS Sejarah kurang diminati oleh peserta didik karena lebih cenderung menjadikan mata pelajaran IPS sejarah sebagai mata pelajaran yang jenuh dan membosankan. Guru IPS masih menggunakan metode konsevional yang monotan, yang pada penerapannya aktivitas guru lebih dominan daripada siswa. Hal ini dikarenakan proses belajar mengajar secara substansi atau isi dari mata pelajaran kurang dekat dengan apa yang menjadi masalah yang dihadapi oleh siswa dalam kehidupan bermasyarakat, berbangsa dan bernegara. Di sisi lain karena cara penyajian yang kurang dapat membangkitkan minat belajar siswa yang pada akhirnya berpengaruh terhadap kelancaran dari proses belajar dan hasil belajar siswa yang kurang memuaskan sehingga keberhasilan dari tujuan pendidikan secara umum tidak dapat tercapai.

Berdasarkan hal tersebut maka perlu diadakan perbaikan terhadap strategi pembelajaran yang berkaitan dengan model pembelajaran yang digunakan guru, yaitu dengan menerapkan model pembelajaran kooperatif tipe NHT (Numbered Heads Together) (Isjoni., 2010). Model pembelajaran kooperatif tipe NHT ini lebih melibatkan siswa secara langsung untuk aktif dalam pembelajaran. Jadi dengan diterapkannya model pembelajaran ini diharapkan dapat meningkatkan minat dan hasil belajar siswa terhadap pelajaran IPS Sejarah.

Model pembelajaran yang dianggap mampu membagi perubahan tersebut adalah dengan menerapkan model pembelajaran kooperatif tipe Numbered Heads Together (NHT). Dimana dengan menerapkan model pembelajatran ini, siswa akan mampu bertanggung jawab karena siswa berperan langsung sebagai penyalur materi kepada teman-temannya dan akan mampu menemukan permasalahan-permaslahan dalam belajar dan akan mencari jawaban dari permasalahan tersebut. Sehingga siswa akan mampu belajar mandiri untuk 
menemukan hal-hal yang berkaitan dengan pelajaran.

Pembelajaran kooperatif adalah proses pembelajaran yang memupuk kebersamaan yang kuat, kerjasama yang baik dan mampu membangkitkan intelektualitas siswa dengan optimal. Pembelajaran kooperatif secara sadar menciptakan interaksi yang silih asih sehingga sumber belajar bagi siswa bukan hanya guru dan bahan ajar, tetapi juga sesama siswa (Aunurahman., 2010). Dalam pembelajaran koopetaif dikenal berbagai metode pembelajaran salah satunya adalah metode Numbered Head Together (NHT). NHT merupakan pendekatan struktur informal dalam kooperative learning.

Berdasarkan hal tersebut di atas, setelah peneliti melakukan observasi di SMP N 7 Denpasar yaitu di kelas VII.3 pada saat melakukan kegiatan ( Program Pengalaman Lapangan ), KKM yang telah ditentukan oleh sekolah yaitu 70. Dari KKM yang telah ditentukan sekolah banyak siswa yang belum mencapai KKM, sehingga ketuntasan belajar dan hasil belajar siswa belum maksimal. Kondisi seperti ini tentunya tidak boleh di diamkan, harus ada upaya-upaya yang dilakukan guru dalam usaha untuk meningkatkan minat belajar siswa agar hasil belajarnya lebih meningkat. Sehingga melihat kenyataan tersebut peneliti merasa tertarik untuk melakukan penelitian dengan judul Penerapan Model Pembelajaran Kooperatif tipe Numbered Heads Together (NHT) untuk Meningkatkan Minat dan Hasil Belajar IPS pada Siswa kelas VII.3 SMP N 7 Denpasar tahun pelajaran 2018/2019.

\section{METODE PENELITIAN}

Penelitian Tindakan Kelas (PTK) adalah penelitian yang dilakukan oleh guru di kelasnya sendiri melalui refleksi diri dengan tujuan untuk memperbaiki kinerjanya sehingga hasil belajar meningkat (Arikunto, 2009). Penelitian tindakan kelas berasal dari bahasa Inggris Classroom Action Research, yang berarti penelitian yang dilakukan pada sebuah kelas untuk mengetahui akibat tindakan yang diterapkan pada suatu subyek penelitian di kelas tersebut (Arikunto, 2011). Pada penelitian ini, peneliti akan menggunakan rancangan deskriptif kualitatif model Kurt Lewin sebanyak dua siklus. Dimana setiap siklus disini terdiri dari empat komponen yakni : perencanaan, pelaksanaan tindakan, observasi dan refleksi

\section{HASIL PENELITIAN DAN PEMBAHASAN}

\section{Deskripsi Hasil Penelitian}

Berdasarkan data hasil belajar siswa pada semester 1 ( Tabel 4.1) dapat dikatakan bahwa hasil belajar IPS siswa kelas VII.3 SMPN 7 Denpasar belum mencapai hasil yang memuaskan. Dalam hal ini peneliti melakukan perbaikan pada model pembelajaran dengan menggunakan model pembelajaran tipe NHT (Numbered Heads Together) sebagai acuan dan strategi untuk digunakan dalam menyampaikan materi pembelajaran guna mencapai hasil belajar yang baik

1. Pada data hasil evaluasi sebelum penelitian yang diketahui dari 36 siswa 22 siswa memperoleh nilai di bawah 70, sedangkan 14 orang siswa memperoleh nilai $70 \mathrm{ke}$ atas yang berarti ketuntasan klasikalny 
$\frac{36-22}{36} \times 100 \%=38,8 \%$ dan ratarata kelas menjadi 6,36 hasil yang terlihat di atas sebanyak $38,8 \%$ siswa sudah tuntas sementara sisanya $61,1 \%$ belum tuntas karena nilai KKM yang berlaku adalah 70 .

2. Pada siklus I minat belajar siswa dari 36 siswa memperoleh nilai ratarata 7,0 yaitu tergolong dalam kategori cukup. Sedangkan hasil belajar siswa pada aspek Ranah Kognitif rata-rata $6,75 \%$, Ranah Afektif nilai Amat Baik 27,7\%,

\section{PEMBAHASAN}

Pengaruh Model Pembelajaran kooperatif tipe Numbered Heads Together terhadap Peningkatan Minat Belajar Siswa Berdasarkan proses pembelajaran pada siklus I dan siklus II, melalui pembelajaran dengan menggunakan model pembelajaran NHT (Numbered Heads Together) peserta didik semakin menunjukan adanya peningkatan minat belajar pada mata pelajaran Ilmu Pengetahuan Sosial (IPS) Sejarah. Peserta didik sudah mulai fokus dalam belajar, dan kerja sama antar kelompok dengan baik Pengaruh Model Pembelajaran tipe Numbered Heads Togerher terhadap Hasil Belajar Siswa

Setelah dilakukan penelitian selama proses pembelajaran IPS Sejarah dengan materi "Interakasi Sosial dan Lembaga Sosial " maka diperoleh gambaran bahwa hasil pelaksanaan tindakan dengan model pembelajaran tipe NHT (Numbered Heads Together) secara keseluruhan hasil belajar sudah memuaskan. Dilihat dari hasil belajar
Baik 58,3\%， Cukup 13,3\% sedangkan Aspek Psikomotor nilai Amat Baik 68,3\%, Baik 27,7\%, dan Cukup 8,3\%.

3. Pada siklus II minat belajar siswa rata-rata 11,08 yaitu tergolong "Tinggi". Minat belajar siswa telah optimal karena telah mencapai kriteria yang diharapkan yaitu tergolong "Cukup Tinggi". Sedangkan hasil belajar siswa pada Aspek Kognitif nilai rata-rata $80 \%$, Afektif Amat Baik 83\%, Baik 83\%, sedangkan Ranah Psikomotor nilai Amat Baik 94,4\%, Nilai Baik 5,5\%

siswa terjadi peningkatan dari siklus I ke siklus II dengan rata-rata $6,75 \%$ menjadi $80 \%$ dan ketuntasan belajar 52\% menjadi $100 \%$.

Dengan demikian hasil belajar siswa dalam memahami materi pelajaran dengan menggunakan model pembelajaran NHT (Numbered Heads Together) terbukti dapat meningkatkan hasil belajar dalam dua siklus. Siswa bukan hanya aktif menjawab tetapi juga aktif dalam bertanya dan berdiskusi antar kelompok. Di samping itu dari hasil wawancara kepada siswa diperoleh bahwa dengan menggunakan model pembelajaran NHT (Numbered Heads Together) proses belajar menjadi lebih aktif dan menyenangkan.

Berdasarkan hasil penelitian sebelum dan sesudah (siklus I dan silkus II) bahwa penerapan model pembelajaran NHT (Numbered Heads Together) dapat meningkatkan minat dan hasil belajar siswa terutama mata pelajaran IPS (Ilmu Pengetahuan Sosial) Sejarah. 


\section{PENUTUP}

\section{Simpulan}

Berdasarkan hasil penelitian siklus I dan siklus II beserta pembahasan pada bab IV, maka dapat dirumuskan kesimpulan sebagai berikut :

1. Penerapan model pembelajaran kooperatif NHT (Numbered Heads Together) dapat meningkatakan minat dan hasil belajar siswa dengan ditunjukkan adanya partisipasi berdasarkan hasil Ranah Kognitif, Afektif dan Psikomotor serta antusias siswa untuk mengemukakan pendapat maupun menanggapi pendapat dalam diskusi kelompok, kebersamaan serta keakraban dalam kelompok juga menunjang peningkatan minat dan hasil belajar siswa.

2. Penggunaan model pembelajaran tipe NHT (Numbered Heads Together) dalam proses pembelajaran sangat efektif karena dengan model ini siswa bisa belajar berkelompok dan berpartisipasi aktif dalam kelompoknya masingmasing, selain model Numbered Heads Together yang merupakan bagian dari pembelajaran kooperatif membuat proses pembelajaran dalam kelas menjadi menarik dan menyenangkan siswa yang awalnya hanya belajar dengan metode ceramah mengalami kesulitan pada saat menjawab soal yang belum mereka dapatkan di buku, namun dengan model pembelajaran Numbered Heads Together siswa mulai merubah cara belajar dan hasilnya sangat baik dan efektif.

\section{DAFTAR PUSTAKA}

Arikunto, S. (2009). Penelitian Tindakan Kelas. Aksara., Bumi.

Arikunto, S. dkk. (2011). Penelitian Tindakan Kelas. PT. Bumi Aksara.

Aunurahman. (2010). Belajar dan Pembelajaran. Alfabeta.

Isjoni. (2010). Pembelajaran Kooperatif. Pustaka Pelajar. 